\author{
Karolina Starego \\ Uniwersytet Gdański \\ E-MAIL: karolina.starego@ug.edu.pl \\ Alicja Korzeniecka-Bondar \\ Uniwersytet w Bialymstoku \\ E-MAIL: alibon@poczta.fm
}

\title{
Polityczne konteksty edukacji
}

Zarezerwowane jeszcze kilkadziesiąt lat temu głównie dla krytycznych studiów nad edukacją twierdzenie o istnieniu koniecznych związków polityki i edukacji stało się dziś przyjętym paradygmatem myślenia w pedagogice. Polityczność uznana została już nie tylko za możliwą, i co należy podkreślić, negatywnie waloryzowaną „przypadłość” edukacji, ale za przynależną jej istocie. O ile więc immanentnie dla edukacji rozumiana polityczność opisywana jest wkategoriach stanu faktycznego, o tyle za zdecydowanie niepożądane uważa się niektóre, czy też zyskujące charakter dominujących, formy jej upolitycznienia (Rutkowiak, Szczepska-Pustkowska, 1995), wiązanego również z bezpośrednią ingerencją w obszar edukacji zróżnicowanych grup interesu (Śliwerski, 2015). Oznacza to, że nie możemy mówić o jakimś pozapolitycznym apolitycznym stanie idealnym, i co więcej, że zróżnicowane formy upolityczniania edukacji stanowią historyczne oraz akcydentalne, ale nieuniknione formy realizacji jej polityczności (Rutkowiak, Szczepska-Pustkowska, 1995).

Obecne, a początkowo przyjmowane jedynie na gruncie pedagogiki krytycznej, twierdzenie o niemożliwości rozdzielenia tego co polityczne od tego co edukacyjne (Szkudlarek, 2009), może być konceptualizowane na kilka różnych sposobów, każdorazowo zależnych od zakładanego typu relacji między edukacją a szerszą rzeczywistością społeczną. W pierwotnie dominującym ujęciu strukturalistyczno-funkcjonalistycznym, i w kluczowej dla niego teorii reprodukcji ekonomicznej lub kulturowej, edukacja oraz związane $z$ nią instytucje postrzegane są wyłącznie jako epifenomen szerszych zasięgiem procesów ekonomiczno-politycznych i kulturowych. Przykładem mogą być tu koncepcje Pierre'a Bourdieu, Louisa Althussera, Samuela Bowlesa i Her- 
berta Gintisa. Polityczność edukacji wynika tu z jej podporządkowania celom wyznaczanym w innym obszarze, bez względu na to, czy odzwierciedlają one również intencjonalnie projektowane cele emancypacyjne.

$\mathrm{Z}$ nieco odmiennym ujęciem polityczności mamy do czynienia w poststrukturalistycznych koncepcjach pedagogiki krytycznej, charakteryzujących się próbą integracji wymiaru strukturalnego i podmiotowej agencji oraz bardziej dialektycznym ujęciem relacji między edukacją a polityką i ekonomią. W tym przypadku polityzacji ulega cała kultura (Giroux, 1983). W efekcie edukacja i związane z nią instytucje nie tylko przestają pełnić funkcję jedynie instrumentów transmisyjnych, stając się jednocześnie przestrzenią, w której ujawnia się antagonizm, walka o znaczenia oraz niezależna produkcja kulturowa, jak u Paulo Freirego i kontynuatorów, Henry’ego Giroux, Paula Willisa, Petera McLarena, Michaela Apple'a.

To afirmatywne, polemizujące $\mathrm{z}$ pesymizmem determinizmu podejść strukturalnych (Giroux, 1983), ujęcie kultury szkoły w jej wymiarze politycznym nieuchronnie wiąże się z szeregiem wysuwanych wobec jej pracy oczekiwań o charakterze normatywnym. Preskryptywne ujęcia polityczności edukacji widzą zatem w jej działaniu jedno z głównych źródeł możliwej zmiany politycznej, przybierającej postać strukturalnej rekonstrukcji społecznej o charakterze radykalnym i progresywnym (Paulo Freire, Ivan Illich, Peter McLaren) bądź tożsamościowej, wtórnie lub na zasadzie sprzężenia zwrotnego warunkującej przeobrażenia strukturalne (koncepcje inspirowane Foucaultem, Rancière'em). Bardziej „separatystyczne” odmiany konceptualizacji polityczności - w wersji „postkrytycznej” (Hodgson, Vlieghe, Zamojski, 2017) - mniej lub bardziej lokujące się w koncepcji myślenia politycznego Hannah Arendt, apelują z kolei o wyraźne oddzielenie tego co polityczne i społeczne od tego co edukacyjne, oraz o zawieszenie demaskatorskich i utopistycznych pretensji teorii krytycznej jako warunków rzeczywiście odnawiającej politycznej pracy edukacji; natomiast w wersji „politycznie postpolitycznej” (Szwabowski, 2017), czerpiącej z praktyk teoretycznych postoperaizmu Michaela Hardta i Antonio Negriego, propagują „wielościową" „politykę rzeczy małych” lub/i Agambenowsko rozumianą pracę zawieszenia i odmowy (Szwabowski, 2017; Lewis, 2015).

Polityczność rozumiana jest również bardziej ontologicznie. Oznacza to teoretyczny zabieg rozdzielenia obszaru warunków możliwości od warunkowanych przez nią rzeczywistych praktyk politycznych (Laclau, Mouffe, 2007). O ile we wcześniej sygnalizowanych podejściach edukacja w swojej praktyce teoretycznej lokowana była w warunkowanym danym rozumieniem polityczności polu tego co polityczne, tak teraz staje się, ontologicznie rzecz ujmując, 
bezpośrednio odpowiedzialna za wytwarzanie nowej rzeczywistości. Jak pisze T. Szkudlarek, rozpoczynająca się wraz z Platonem długa intelektualna tradycja myślenia o związkach polityki i edukacji ujmuje tę drugą jako część olbrzymiego, często utopijnego, politycznego projektu budowania "lepszego" społeczeństwa - bez względu na ideologiczną proweniencję pomysłu na jego realizację (2013). Tym samym żaden projekt polityczny, konstruujący normatywne stany docelowe oraz performatywne projekcje pożądanej rzeczywistości społecznej, nie byłby możliwy bez właściwej językowi teorii edukacyjnej „ontologicznej” retoryki (2017). Oznacza to, że edukacyjna teoria, a za nią sama edukacja, nie tylko stanowią obszar realizacji politycznych wizji oraz interesów, ale że sama logika polityczna nie jest możliwa do oddzielenia od urzeczywistniającego ją języka teorii edukacji.

Mimo iż, jak na początku zaznaczono, założenie o koniecznym związku polityczności i edukacji zyskało rangę aksjomatu dla wielu ujęć teoretycznych oraz przedsięwzięć badawczych, to nadal, zwłaszcza obecnie, mamy do czynienia z próbami depolityzacji edukacji na poziomie polityk publicznych i praktyk instytucjonalnych, przy jednoczesnym, bardziej niż kiedykolwiek zauważalnym, rozprzestrzenieniu się retoryki edukacyjnej w obszarach pierwotnie z edukacją niezwiązanych (Czyżewski, 2013). Zjawisko, w literaturze przedmiotu określane jako edukacjonalizacja (Depaepe \& Smeyers, 2008; Smeyers \& Depaepe, 2008) wiąże się z przybierającymi zróżnicowaną formę, neoliberalnymi próbami prywatyzacji i indywidualizacji problemów społecznych, a prościej rzec ujmując, ze scedowaniem na ręce jednostek odpowiedzialności za edukację, która traci tym samym swój wymiar publiczny i staje się przedsięwzięciem o charakterze prywatnym. Jedną z najbardziej niebezpiecznych, a aktualnie nam towarzyszących konsekwencji tego procesu - ze względu na jego dramatyczne konsekwencje społeczne - jest restytucja tego co polityczne w karykaturalnych, ale nie mniej niebezpiecznych formach (Mouffe, 2005) radykalnej, faszystowskiej polityki publicznej, tożsamościowej i edukacyjnej. Ta ponura perspektywa, z której dalekosiężnymi konsekwencjami przyjdzie nam się jeszcze zmierzyć, powoduje, że problem odnowienia dyskusji nad politycznymi kontekstami oraz politycznością edukacji staje się tym bardziej palący.

Przedłożony Czytelniczkom i Czytelnikom numer „Parezji”, poświęcony politycznym kontekstom edukacji, stanowi próbę włączenia się do dyskusji na temat nie tylko aktualnych zagrożeń, ale i możliwości, jakie wynikają z przemyślanej na nowo politycznej i politycznie zorientowanej edukacji.

W artykule Polityka $w$ edukacji i edukacja $w$ polityce, Anna Babicka-Wirkus podejmuje problematykę politycznego uwikłania edukacji. Autorka 
wskazuje na dialektyczność tytułowego związku, jednocześnie ukazując jego konsekwencje dla procesu emancypowania się podmiotu. Ramą teoretyczną prowadzonych rozważań uczyniła teorię Jacques'a Rancière’a, a w szczególności jego rozróżnienie dwóch wymiarów, decydujących o kształcie rzeczywistości społecznej - policji i polityki. O ile celem działania policji jest wprowadzanie ładu i bezpieczeństwa, polityka stanowi anarchizujące wydarzenie rozbijające ustalony porządek i wprowadzające ryzyko nieprzewidywalnych zmian. Jest ona jednak, w ujęciu Autorki, kluczową siłą zmieniającą obowiązującą gramatykę szkoły, edukacji i społeczeństwa.

Piotr Kowzan poszukuje odpowiedzi na pytanie: jaką edukację polityczną warto rozwijać we współczesnej polskiej szkole i wszędzie tam, gdzie buduje się w ludziach zdolność do wspólnej i niewyalienowanej pracy. Kierunek rozważań zawartych w tekście Edukacja wobec groźby wojny wyznaczyła konieczność ustosunkowania się myśli pedagogicznej - i równoległego dostosowania praktyk wychowawczych - do zmian w sposobie koordynacji społeczeństwa, które dokonują się w atmosferze groźby wybuchu wojny. Autor bazował na dotychczasowych badaniach własnych z obszaru uczenia się w ruchach społecznych, analizując trzy porządki zapewniające koordynację społeczeństw (neoliberalizm, nacjonalizm, militaryzm) w kontekście wykluczanych przez nie wartości: dobra wspólnego, samorządu i pokoju. Rezultatem pracy jest matryca przyporządkowująca te kontrwartości różnym typom współpracy (koordynacji, kooperacji i kolaboracji).

Zasadniczym celem tekstu Od pedagogiki emancypacyjnej do filozofii Marksa, czyli o alfabetyzacji ekonomicznej we Freirowskim elementarzu dla dorosłych „A Luta Continua” autorstwa Piotra Stańczyka jest przedstawienie programu alfabetyzacji ekonomicznej, zawartego we Freirowskim elementarzu A Luta Continua. Opisywana akcja alfabetyzacyjna skończyła się spektakularnym sukcesem ze względu na koncentrację na zagadnieniach warunków materialnych codziennej egzystencji osób uczących się. Analiza tekstów zawartych w omawianym podręczniku wskazała na istotność kwestii socjalnej oraz pozwoliła zwrócić uwagę na ważną rolę, jaką odgrywa filozofia Marksa w programie alfabetyzacji ekonomicznej. W związku z dostrzeganą obecnie w pedagogice „alergią” na filozofię Marksa (Szkudlarek, 2009) oraz fakt, że marksizm dezawuuje się jako teorię paraliżującą działania na rzecz zmiany społecznej, artykuł zawiera rozbudowane wprowadzenie służące ulokowaniu filozofii wychowania Freirego w dyskursie pedagogiki krytycznej. W tekście znajdują się także: rekonstrukcja początków stosowania „metody Freirego" oraz analiza czytanek stanowiących trzon programu alfabetyzacji ekonomicznej. 
Oskar Szwabowski zaprasza czytelników do lektury nietypowego w przestrzeni akademickiej tekstu. Nocne studiowanie $z$ Bartlebym jest wyprawą bez mapy. Tekst należy traktować jako spotkanie, w którym uczestniczy milczący Bartleby. Spotkanie jest wydarzeniem nieprzewidywalnym - podobnie jak tekst Oskara Szwabowskiego.

Rozmowa prowadzona przez Karolinę Starego z Profesor Joanną Rutkowiak dotyczy szeroko pojętych, politycznych kontekstów edukacji oraz problemu jej polityczności i upolitycznienia. Koncentrując się zarówno na współczesnych zjawiskach, takich jak neoliberalizm, postprawda, brutalizacja i faszyzacja przestrzeni publicznej oraz przeszłych, jak transformacja ustrojowa, rozmówczynie wskazały nie tylko na związane z nimi edukacyjne zaniedbania, ale również odsłoniły kierunek, w jakim powinien pójść odpowiedzialny społecznie i wrażliwy na polityczny kontekst edukacji, teoretyczny namysł pedagogiki.

Z kolei rozmowa Karoliny Starego z Profesorem Tomaszem Szkudlarkiem koncentruje się na zagadnieniach polityczności edukacji oraz politycznego charakteru teorii edukacyjnej. Rozmówcy skupiają się na wymiarze tożsamościowym i identyfikacyjnym podejmowanej problematyki. Kluczowe dla tegoż zagadnienie performatywności edukacyjnej retoryki oraz ontologii teorii edukacyjnej rozwijane jest w perspektywie politycznej koncepcji Ernesta Laclau oraz w kontekście współczesnych zjawisk społecznych i politycznych, takich jak transformacja ustrojowa, zagrożenie autorytaryzmem oraz faszyzacja przestrzeni publicznej.

Zmiana polskich podstaw programowych kształcenia ogólnego wzakresie kompetencji społecznych i obywatelskich stała się przedmiotem analiz podjętych przez Violettę Kopińską. Autorka zaprezentowała wyniki badań własnych, których celem było ustalenie zakresu zmian nowych podstaw programowych kształcenia ogólnego w odniesieniu do artykułowanych tam kompetencji społecznych i obywatelskich. Metodą zbierania danych zastosowaną w badaniach było przeszukiwanie źródeł wtórnych, a metodą analizy danych - analiza treści. Analiza wyników badań wskazała, że „nowa” podstawa programowa utrwala, podobnie jak „stara”, tradycyjny - transmisyjny model edukacji i obywatelstwo socjalizacyjne. Wniosek ten wynika zarówno z ogólnej analizy struktury zapisanych tam wymagań, jak i analiz szczegółowych, odnoszących się zarówno do eksponowanych, jak i marginalizowanych kategorii analitycznych.

Łukasz Stankiewicz dokonał recenzji książki Samuela Bowlesa The Moral Economy: Why Good Incentives Are No Substitute for Good Citizens (Yale University Press, 2016). Omawiana pozycja jest podsumowaniem pracy 
autora w ramach interdyscyplinarnego pola badań nad ludzką zdolnością do współpracy. Celem publikacji Bowlesa jest opis interakcji pomiędzy bodźcami ekonomicznymi i moralnymi, mający na celu udoskonalenie narzędzi służących tworzeniu polityk państwowych.

Numer zamyka sprawozdanie z czwartego kolokwium Sieci Badawczej „Solidarity in Diversity” (23-24 stycznia 2018, Gandawa, Belgia) przygotowane przez Piotra Zamojskiego. Ta sieć badawcza założona przez prof. Stijna Oosterlyncka (Uniwersytet w Antwerpii) i ufundowana przez Flandryjską Fundację Badawczą (FWO) od czerwca 2016 spotyka się dwa razy w roku. Celem tego międzynarodowego i multidyscyplinarnego konsorcjum jest konceptualizacja solidarności w społeczeństwach złożonych.

\section{BIBLIOGRAFIA}

Czyżewski, M. (2013). W kręgu społecznej pedagogii. Societas/Communitas. Pedagogizacja życia społecznego, 2 (16), 43-74.

Depaepe, M., Smeyers, P. (2008). Educationalization as an Ongoing Modernization Process. Educational Theory, 58 (4), 379-389.

Giroux, M. (1983). Theories of reproduction and resistance in the new sociology of education: A critical analysis. Harvard Educational Review, 53 (3), 257-293.

Hodgson, N., Vlieghe, J., Zamojski, P. (2017). Manifesto for a Post - Critical Pedagogy. Punctum Books.

Laclau, E., Mouffe, C. (2007). Hegemonia i socjalistyczna strategia. Przyczynek do projektu radykalnej polityki demokratycznej. Wrocław: Wydawnictwo Dolnośląskiej Szkoły Edukacji.

Lewis, T.E. (2013). On study: Giorgio Agamben and educational potentiality. London: Routledge.

Mouffe, C. (2005). On the political. London. New York: Routledge.

Rutkowiak, J., Szczepska-Pustkowska, M. (1995). Polityczność a upolitycznienie wychowania (W oparciu o teoretyczną rekonstrukcję fenomenu „pedagogika socjalistyczna”). W: J. Rutkowiak (red.), Odmiany myślenia o edukacji, Kraków: Oficyna Wydawnicza „Impuls".

Smeyers, P., Depaepe, M. (eds.) (2008). Educational Research: The Educationalization of Social Problems, vol. 3. Netherlands.

Szkudlarek, T. (2009). Wiedza i wolność w pedagogice amerykańskiego postmodernizmu. Kraków: Oficyna Wydawnicza „Impuls”.

Szkudlarek, T. (2013). Introduction (s. 1-13). W: Education and the Political. Rotterdam: SensePublishers.

Szkudlarek, T. (2017). On the Politics of Educational Theory. Rhetoric, theoretical ambiguity, and the construction of society. London, New York: Routledge.

Szwabowski, O. (2017). Polityczność dydaktyki. Hybris, 36, 60-72.

Śliwerski, B. (2015). Edukacja (w) polityce. Polityka (w) edukacji. Inspiracje do badań polityki oświatowej. Kraków: Oficyna Wydawnicza „Impuls”. 